\title{
Comparison of Comparative Advantage of Korea and China by Technology Level
}

\author{
Jung Taik Hyun, * Jin Young Hong**
}

\begin{abstract}
In this paper, we examine the comparative advantage of Korea and China while focusing on their technology level. The three digit SITC (Standard International Trade Classification) data is classified by technology level and the revealed comparative advantage (RCA) is derived from 1992-2009 by using UN COMTRADE data. For careful interpretation of the comparative advantage and technology levels, we also examined intra-industry trade and unit values of bilateral Korea-China trade, and semi-conductor industry technology. We found that the revealed comparative advantage has moved from low technology products to high technology products in Korea. China still maintains a comparative advantage in low technology products such as textiles and clothing, but at the same time, China's high and medium-high technology products have recently gained a comparative advantage. The perception that China only has a comparative advantage for labor intensive products with low technology should be changed based on our analysis. However, China's advancement in technology should not be overestimated. When comparing the unit value of basic materials of Korea's and China's exports, we found that Korea's export product prices are on average higher than that of China's, although the gap is reducing. A wider technology gap between Korea and China still exists in the semi-conductor industry, which is one of the most advanced high technology industries throughout the world.
\end{abstract}

Keyword : comparative advantage, technology level, intra-industry trade, Chinese trade, Korean trade

Submission Date: 11/15/2011 Revision Date: 11/25/2011 Acceptance Date: 11/25/2011

* Professor, Department of International Trade, Inha University, Korea E-mail:jthyun@inha.ac.kr

** Research Fellow, Jung seok Research Institute, Korea E-mail:jyhong@inha.ac.kr 


\section{Introduction}

Comparative advantage changes over time. In particular, rapidly growing economies like Korea and China experience dynamics of trade performance, and the composition of export and import products are quickly changing. The technology level of export and import products also seems to have changed dramatically. When Korea launched its First Five Year Economic Development Plan in 1962, its main export items were plywood and wig, which are mostly labor-intensive and low technology products. Korea now exports semi-conductor chips and Samsung's smart phones are competing with the i-phone of Apple, the world's leading company for information technology. After adopting Deng Xiao Ping's open door policy in 1978, China began to export textiles, toys and footwear, and most of China's export products in the early stages were low cost labor-intensive products. China's trade structure has changed after 30 years of fast growth, and has seemed to gain competitiveness in higher technology level products. In Korea, there is concern that competition with China will continue to grow and China's increasing technology will soon become a threat to Korea's economy.

In this paper, we try to examine the comparative advantages of Korea and China while focusing on technology levels. Our analysis is based on the revealed comparative advantage (RCA) that we have derived from the 1992-2009 UNCOMTRADE data. When using the OECD classification technology levels, the three digit SITC (Standard International Trade Classification) data is classified by the technology level and the RCA is calculated for each technology level. We examined if the comparative advantage of Korea and China had moved from low technology level products to medium and high technology level products. We also checked whether the perception that China has a comparative advantage in low technology industries is still valid. In particular, we compared the competitiveness of Korea's products with China's by evaluating the technology level, and we tried to find out if China is a real threat to Korea's high technology exports in the world market. In order to overcome the weaknesses of RCA, we also examined the extent of intra-industry trade between Korea and China, and tried to draw its implications with regards to RCA interpretation and the technology gap. We also analyzed the unit values of Korea's and China's export products, and examined the technology differences in the semi-conductor chip industry, one of the most advanced high-tech industries.

In Section 2, we describe our methodology and data. The concept and measurement of the revealed comparative advantage (RCA) which was developed by Balassa (1965) will be explained. Two kinds of measurement methods - RCA in the world market and the specific market - are illustrated. The data source, industry and product classification by technology will be illustrated. Section 3 has seven sub-sections and can be broadly divided into two 
parts. The first part focuses on measuring RCA in Korea and China. RCA within the world market is presented by the industry and technology level. RCA within the bilateral trade flow between Korea and China is somewhat different from those in the world market which is illustrated. The second part is a complimentary analysis for the careful interpretation of the comparative advantage and technology levels of Korea and China. Intra-industry trade, unit value and semi-conductor industry technology analysis are all performed. Section 4 summarizes our findings and draws conclusions to the comparison of comparative advantage and the technology levels of Korea and China.

\section{Method and Data}

The concept and calculation of revealed comparative advantage (RCA) was developed by Balassa (1965). Although many modified versions of RCA have been suggested since Balassa's seminal paper1), we use the basic form of RCA here.

$$
R C A_{i j}=\left(X_{i j} / \Sigma_{i} X_{i j}\right) /\left(\Sigma_{i} X_{i j} / \Sigma_{i} \Sigma_{j} X_{i j}\right)
$$

Where $X_{i j}$ is country $i$ 's export in $j$ industry. The numerator indicates the share of country $i$ 's $j$ industry exports in total $j$ industry exports throughout the world. The denominator indicates the share of country $i$ 's exports in total world exports. If the RCA has a value greater than 1 , country $i$ seems to have a comparative advantage in industry $j$, and if the value is less than 1 , the country has a disadvantage in the industry.

Comparative advantage can be measured within a specific market as well as within the world market. For example, Korea's chemical industry does not exhibit a comparative advantage in the world market on average, but has a comparative advantage in China. In order to examine the comparative advantage within a specific market, we use the following.

$$
R C A_{i j k}=\frac{X_{i j k} / \Sigma_{i} X_{i j k}}{\Sigma_{j} X_{i j k} / \Sigma_{i} \Sigma_{j} X_{i j k}}
$$

Where $k$ denotesthe destination market for the calculation of RCA. So if $i$ is Korea and $k$ is China, and the $R C A_{i j k}$ is greater than 1 , Korea's $j$ industry has a comparative advantage in the Chinese market.

1) See Brasili et al (2000), Dalum et al (1998), and Hyun and Tcha (2007) for example. 
The revealed comparative advantage has merits and disadvantages. One merit may be that RCA gives us explicit numerical criteria for the theoretically developed concept of comparative advantage. One weakness of RCA is that it is based on the total value of export products, and not on the true value added accrued in the country. Since global production sharing is quickly increasing and the production process of a single item is performed in many different countries, RCA indices that are drawn from trade statistics should be interpreted carefully with other indicators being taken into account. In this regard, we examined intra-industry trade between Korea and China. We also compared the unit value of Korea's and China's export products, and examined the differences in technology levels in the semi-conductor industry.

The 1992-2009 UNCOMTRADE data for Korea, China and the world total have been used. We analyzed the three digit SITC (Standard International Trade Classification) level product classification which has 261 units. We grouped these 3 digit SITC product classifications by technology level in order to find out the RCA in terms of technology. The OECD has a database named STAN (Structural Analysis Database) for analyzing technology levels. The OECD STAN uses industry classifications of ISIC (International Standard Industry Classification), and we converted the ISIC code into a SITC code by using a code matching database provided by the UN statistics division. The conversion and the SITC three digit code for the technology level are presented in table 1.

\section{Table 1.}

Technology level and matching SITC code

\begin{tabular}{|c|c|c|}
\hline $\begin{array}{l}\text { Technology } \\
\text { Level }\end{array}$ & ISIC Rev. 3 & SITC 3 Digit (Rev. 3) \\
\hline $\begin{array}{l}\text { High-Technology } \\
\text { manufactures }\end{array}$ & $\begin{array}{c}2423,30 \\
32,33,353\end{array}$ & $\begin{array}{l}541,542,714,751,752,759,761,762,763,764774,776, \\
792,871,872,873,874,881,884,885\end{array}$ \\
\hline $\begin{array}{l}\text { Medium-High } \\
\text { Technology } \\
\text { manufactures }\end{array}$ & $\begin{array}{l}24 \text { less } \\
2423,29 \\
31,34 \\
352+359\end{array}$ & $\begin{array}{l}266,267,342,511,512,513,514,515,516,522,523,524, \\
525,531,532,533,551,553,554,562,571,572,573,574, \\
575,579,591,592,593,597,598,651,712,713,716,721, \\
722,723,724,725,726,727,728,731,733,735,737,741, \\
742,743,744,745,746,747,748,749,771,772,773,775, \\
778,781,782,783,784,785,786,791,793,813,882,891, \\
894,899\end{array}$ \\
\hline $\begin{array}{l}\text { Medium-Low } \\
\text { Technology } \\
\text { manufactures }\end{array}$ & $\begin{array}{l}23,25-28, \\
351\end{array}$ & $\begin{array}{l}325,334,335,344,581,582,583,598,621,625,629,654, \\
661,662,663,665,671,672,673,674,675,676,677,678, \\
679,681,682,683,684,685,686,687,689,691,692,693, \\
694,695,696,697,699,711,718,811,812,893\end{array}$ \\
\hline $\begin{array}{l}\text { Low Technology } \\
\text { manufactures }\end{array}$ & $\begin{array}{l}15-22 \\
36-37\end{array}$ & $\begin{array}{l}0,1,211,232,244,245,246,247,248,251,261,263,264, \\
265,268,269,411,421,422,431,611,612,613,633,634, \\
635,641,642,652,653,654,655,656,657,658,659,821, \\
831,841,842,843,844,845,846,848,851,895,898\end{array}$ \\
\hline
\end{tabular}




\section{The Results}

\section{A. Revealed Comparative Advantage by Industry}

We first measure RCA at industry level. Raw trade data is classified into fifteen industry groups and RCA for each industry is measured by the equation (2.1) and is illustrated in table 2 for Korea and in table 3 for China. In Korea, the textile and clothing industry exhibited the highest RCA of 2.86 in 1992. Next were semi-conductor chips and electronic parts (2.0), information technology equipment and electric appliances (1.65), and transportation equipment other than motor vehicles (1.58). The revealed comparative advantage of Korea's industries changed over time. In 2009, the textile and clothing industry lost its competitiveness with an RCA of 0.59 , and transportation equipment other than motor vehicles exhibited the strongest advantage of 4.30 RCA. In the highest RCA industry, SITC 793 (shipbuilding) was the most important with $97 \%$ of the total share of the industry. Other comparative advantaged industries in Korea in 2009 were precision machinery (2.49), semi-conductor chips and electronic parts (1.59), information technology equipment and electric appliances (1.46), and motor vehicles (1.46). It is noted that the motor vehicle industry was not competitive in 1992, but became competitive in 2009 . Electronic products including information technology had a comparative advantage throughout this time. In short, Korea had a comparative advantage in technology products such as electronics as well as labor intensive products like textiles in 1992, but in recent years, the comparative advantage has been found mainly in the industry groups which produce technology products.

\section{Table 2.}

Revealed comparative advantage by industry for Korea

\begin{tabular}{|c|c|c|c|}
\hline Industry & 1992 & 2000 & 2009 \\
\hline Food and Beverage & 0.31 & 0.24 & 0.14 \\
\hline Textiles and clothes & 2.86 & 1.67 & 0.59 \\
\hline Wood and pulp & 0.24 & 0.46 & 0.47 \\
\hline Chemicals and related products & 0.82 & 0.90 & 0.87 \\
\hline Crude materials and oils & 0.33 & 0.51 & 0.45 \\
\hline Non-metal minerals & 0.36 & 0.27 & 0.18 \\
\hline Basic metals & 1.36 & 1.03 & 1.08 \\
\hline
\end{tabular}




\begin{tabular}{|c|l|l|l|}
\hline Metals manufactures & 1.13 & 0.91 & 1.04 \\
\hline General Machinery & 0.37 & 0.55 & 0.77 \\
\hline Semiconductor \& Electronic parts & 2.00 & 1.77 & 1.59 \\
\hline IT equipment \& home appliances & 1.65 & 1.88 & 1.56 \\
\hline Transport equipment - Cars & 0.57 & 1.01 & 1.46 \\
\hline Transport equipment - except cars & 1.58 & 1.95 & 4.30 \\
\hline Precision machinery & 0.42 & 0.35 & 2.49 \\
\hline Miscellaneous manufactures & 0.62 & 0.26 & 0.14 \\
\hline
\end{tabular}

Source: Authors own calculation from UNCOMTRADE data

* Unless specified otherwise, tables and figures in this paper are from the authors calculation based on UNCOMTRADE data.

In China, a comparative advantage was revealed in low skilled labor intensive industries in 1992. The textiles and clothing industry exhibited the highest RCA of 4.12, miscellaneous manufacturing industry (e.g. toys) 1.82, and food and beverage 1.20. Technology intensive industries did not have a comparative advantage: motor vehicles (0.07), semi-conductor chips and electronic parts (0.65), and information technology equipment and electric appliances (0.80). During the period of $1992-2009$, low skilled industries such as food and beverage lost their comparative advantage, but the textiles and clothing industry still maintained the highest RCA (2.95) in 2009. Miscellaneous manufacturing industries also maintained a comparative advantage, although the RCA reduced slightly to 1.52 . It is noted that technology products gained a comparative advantage during the period. The RCA of information technology equipment and electric appliances was found to be 2.88 (close to that of textiles and clothing), and semi-conductor chips and electronic parts 1.37. Motor vehicles still remained uncompetitive (0.25), but precision machinery (1.05), and shipbuilding (1.14) gained a slight comparative advantage in 2009. To summarize China's RCA changes, we can say that China's comparative advantage expanded from the low level technology industry into broader groups of industry including information technology (IT), but labor intensive industries like textiles still maintained their competitiveness. 
Table 3.

Revealed comparative advantage by industry of China

\begin{tabular}{|c|c|c|c|}
\hline Industry & 1992 & 2000 & 2009 \\
\hline Food and Beverage & 1.20 & 0.82 & 0.37 \\
\hline Textiles and clothes & 4.12 & 3.69 & 2.95 \\
\hline Wood and pulp & 0.22 & 0.29 & 0.38 \\
\hline Chemicals and related products & 0.62 & 0.68 & 0.55 \\
\hline Crude materials and oils & 0.82 & 0.33 & 0.13 \\
\hline Non-metal minerals & 1.02 & 0.93 & 0.90 \\
\hline Basic metals & 0.53 & 0.64 & 0.48 \\
\hline Metals manufactures & 1.17 & 1.62 & 1.57 \\
\hline General Machinery & 0.25 & 0.38 & 0.69 \\
\hline Semiconductor \& Electronic parts & 0.65 & 0.99 & 1.37 \\
\hline IT equipment \& home appliances & 0.80 & 1.50 & 2.88 \\
\hline Transport equipment - Cars & 0.07 & 0.19 & 0.25 \\
\hline Transport equipment - except cars & 0.45 & 0.71 & 1.14 \\
\hline Precision machinery & 0.87 & 0.90 & 1.05 \\
\hline Miscellaneous manufactures & 1.87 & 1.71 & 1.52 \\
\hline
\end{tabular}

\section{B. Export Share by Technology Level}

For analysis of the technology level, we first examine the export share in order to get a broad picture. Table 4 exhibits the export share of Korea and China by technology level in the world market. In 1992, low technology products made up 31\% of Korea's exports, and its share was reduced to only $6 \%$ in 2009 . The share of medium-high technology products increased from $27.8 \%$ to $44.9 \%$ during the same period. High technology products increased from $25.4 \%$ to $30.4 \%$ and medium-low technology products remained at a similar level. In China, low technology level products made up more than half (54.7\%) of exports in 1992. Its share reduced a lot, but with a $25.1 \%$ share in 2009 , low level technology products are still important export items for China. Medium-low technology products remained at a similar level like they did in Korea. Medium-high technology products increased from $22.3 \%$ to $28.2 \%$, and high technology products increased more than three folds: from $11.3 \%$ to $34.2 \%$. 
Table 4.

Export share by technology level (\%)

\begin{tabular}{|c|c|c|c|c|c|c|}
\hline \multirow{2}{*}{ Technology Level } & \multicolumn{3}{|c|}{ Korea } & \multicolumn{3}{c|}{ China } \\
\cline { 2 - 7 } & 1992 & 2000 & 2009 & 1992 & 2000 & 2009 \\
\hline Low & 31.0 & 15.3 & 6.0 & 54.7 & 37.4 & 25.1 \\
\hline Medium-Low & 15.9 & 15.5 & 18.7 & 11.7 & 13.1 & 12.5 \\
\hline Medium-High & 27.8 & 32.7 & 44.9 & 22.3 & 27.0 & 28.2 \\
\hline High & 25.4 & 36.4 & 30.4 & 11.3 & 22.5 & 34.2 \\
\hline
\end{tabular}

It seems strange that China's high technology products increased at a faster pace than Korea, and moreover China's high technology share (34.2\%) became larger than Koreas $(30.4 \%)$ in 2009. The reason is that classification is based on finished goods, and not on value added. For example, components for the i-phone 3 are made in fifteen different countries and final step of production is performed in China, so the trade statistics show the whole value of the information technology product as China's export figure. It is very difficult to address this issue correctly when measuring RCA. However, we can try to soften the exaggeration effects by combining high technology groups and medium-high technology groups. According to table 1 which followed the OECD classification, television sets and computers belong to the high technology group, but some parts made for the TV and computer do not. Almost all automobile industry parts and finished goods are classified as medium-high technology products, not fully reflecting the technological progress which has been made in the industry. Therefore, we examined the export share of Korea and China by using three technology levels: low technology, medium-low technology, and high and medium-high technology. The result is illustrated in figure 1 and figure 2.

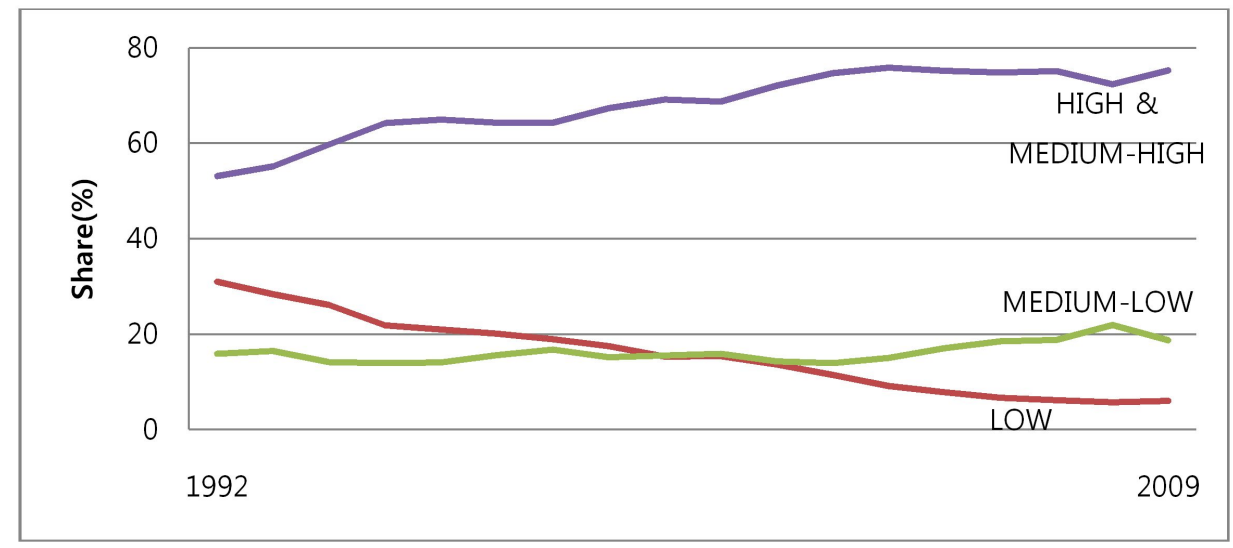

Figure 1.

Export share by technology level in Korea 


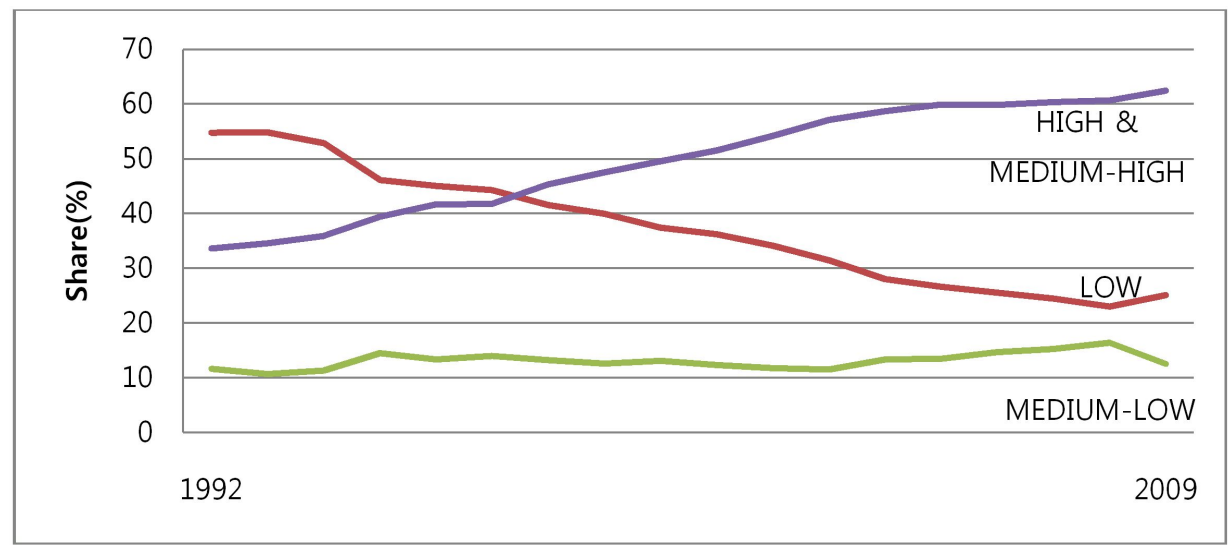

Figure 2.

Export share by technology level in China

By combining high and medium-high technology groups, we found that the group's share in Korea (75.3\%) was still higher than that of China's 62.4\% in 2009. However, it can also be noted that China's exports of high and medium-high technology products increased dramatically during the period.

\section{Revealed Comparative Advantage in the World Market by Technology Level}

We measured the revealed comparative advantage of Korea and China in the world market by technology level. We first calculated it by using four different groups (low, medium-low, medium- high, and high) and the result is presented in table 5. As expected, Korea's comparative advantage in low technology products disappeared. In 1992, the RCA of the low technology products group was 1.33, which implies that the group had a comparative advantage. In 2009, the RCA was reduced to a mere 0.35 meaning that it became a comparatively disadvantaged product. Medium-high technology products were not competitive with a RCA of 0.75 in 1992, but became strongly competitive with a RCA of 1.98 in 2009. High technology products kept their comparative advantage during the period, while medium-low technology products remained at the below unity level of the RCA. China exhibited a strong comparative advantage (2.35) in low technology products in 1992. The RCA of the industry has reduced in China over time, but with a RCA of 1.45, it still retained a comparative advantage in 2009. In 1992, no product group other than low technology products had a RCA value greater than 1, which implies that China only had a comparative advantage in low technology products. In 2009, high technology products 
exhibited a RCA of 1.52 and the RCA of medium-high technology products changed to close to 1 . These RCA numbers for China suggest that China has expanded its export base from low technology products to higher technology products.

\section{Table 5.}

Revealed comparative advantage analysis by technology level (4 groups)

\begin{tabular}{|c|c|c|c|c|c|c|}
\hline \multirow{2}{*}{ Technology Level } & \multicolumn{3}{|c|}{ Korea } & \multicolumn{3}{c|}{ China } \\
\cline { 2 - 7 } & 1992 & 2000 & 2009 & 1992 & 2000 & 2009 \\
\hline Low & 1.33 & 0.85 & 0.35 & 2.35 & 2.07 & 1.45 \\
\hline Medium-Low & 0.77 & 0.65 & 0.67 & 0.56 & 0.55 & 0.45 \\
\hline Medium-High & 0.75 & 1.24 & 1.98 & 0.60 & 0.81 & 0.87 \\
\hline High & 1.33 & 1.49 & 1.35 & 0.60 & 0.92 & 1.52 \\
\hline
\end{tabular}

China's strength in high technology products with a RCA of (1.52) which is higher than Korea's (1.35) should be interpreted carefully. As explained earlier, it is necessary to combine the high technology group and the medium-high technology group, and to measure the RCA of this combined group. The result is presented in table 6, and illustrated in figure 3 and figure 4. Korea's RCA for high and medium-high technology products was 0.95 in 1992 and it increased to 1.37 in 2009. China's RCA for the group was 0.60 in 1992 and it increased to 1.14 in 2009 . We can interpret that Korea was almost ready to move to a comparative advantage position (RCA was close to 1) in 1992 and became competitive and increased competitiveness during the period. China did not have a comparative advantage in the past but recently began to exhibit a modest advantage. We need to also note that the RCA for the low technology industry in China was still the highest among the three groups in 2009 .

\section{Table 6.}

Revealed comparative advantage analysis by technology level (3 groups)

\begin{tabular}{|c|c|c|c|c|c|c|}
\hline \multirow{2}{*}{$\begin{array}{c}\text { Technology } \\
\text { Level }\end{array}$} & \multicolumn{3}{|c|}{ Korea } & \multicolumn{3}{c|}{ China } \\
\cline { 2 - 7 } & 1992 & 2000 & 2009 & 1992 & 2000 & 2009 \\
\hline Low & 1.33 & 0.85 & 0.35 & 2.35 & 2.07 & 1.45 \\
\hline Medium-Low & 0.77 & 0.65 & 0.67 & 0.56 & 0.55 & 0.45 \\
\hline $\begin{array}{c}\text { High \& } \\
\text { Medium-High }\end{array}$ & 0.95 & 1.19 & 1.37 & 0.60 & 0.85 & 1.14 \\
\hline
\end{tabular}




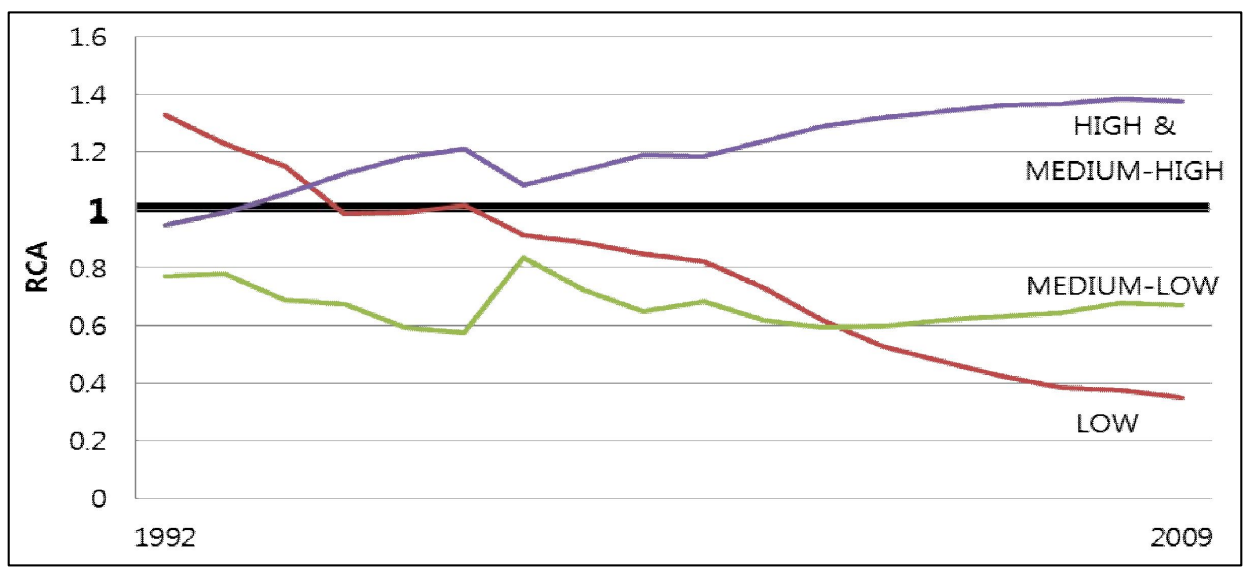

Figure 3.

RCA trend by technology level in Korea

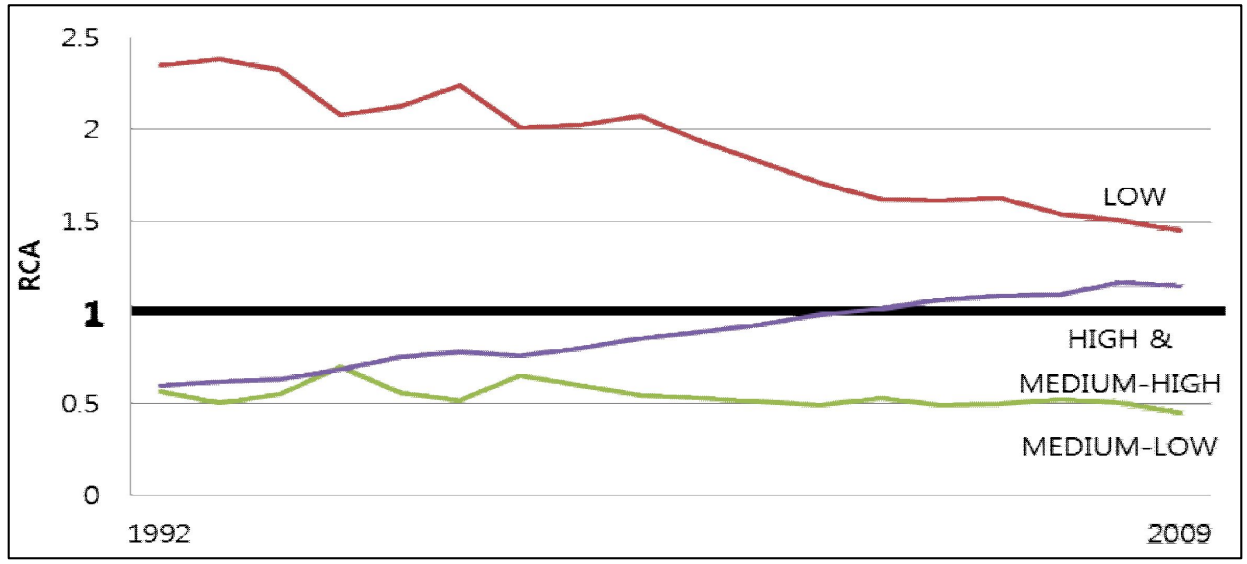

Figure 4.

RCA trend by technology level in China

\section{Revealed Comparative Advantage in Korea- China's Bilateral Trade}

We examined the RCA of Korea's products in China's market and that of China's products in Korea's market. We divide the level of technology into three groups (low, medium-low, and high and medium- high) ${ }^{2}$. The results are illustrated in table 7, and figure

2) We omitted four group analysis here and only explain the results of three group analysis, because combining the high and medium-high technology products provides a more meaningful implication. 
5 and figure 6 . When comparing table 6 and table 7, we can see the difference in revealed comparative advantage in the world market and the specific market. The RCA values in table 7 are closer to 1 , when compared to the corresponding numbers in table 6 . For example, the RCA of Korea's high and medium-high technology products were 1.06 in the Chinese market in 2009, while the world market was 1.37. The interpretation is that Korea's high technology products have a certain comparative advantage in the world market, but its comparative advantage in China does not seem to be quite as obvious (1.06 is close to the neutral number of 1 which means neither an advantage nor disadvantage) . China's low technology products still maintained a substantial comparative advantage in the world market with a RCA of 1.45 in 2009, but its advantage in Korea was reduced to a moderate 1.14. Interestingly, Korea's medium-low technology products which exhibited a comparative disadvantage in the world market with a RCA of 0.67 were discovered to have a comparative advantage although at a minimum level of 1.05.

\section{Table 7.}

Korea's RCA in the Chinese market and China's RCA in the Korean market

\begin{tabular}{|c|c|c|c|c|c|c|}
\hline \multirow{2}{*}{ Technology Level } & \multicolumn{3}{|c|}{ Korea } & \multicolumn{3}{c|}{ China } \\
\cline { 2 - 7 } & 1992 & 2000 & 2009 & 1992 & 2000 & 2009 \\
\hline Low & 0.93 & 1.21 & 0.49 & 2.69 & 2.59 & 1.15 \\
\hline Medium-Low & 2.34 & 1.37 & 1.05 & 1.48 & 1.13 & 0.79 \\
\hline High \& Medium-High & 0.68 & 0.86 & 1.06 & 0.32 & 0.62 & 1.06 \\
\hline
\end{tabular}

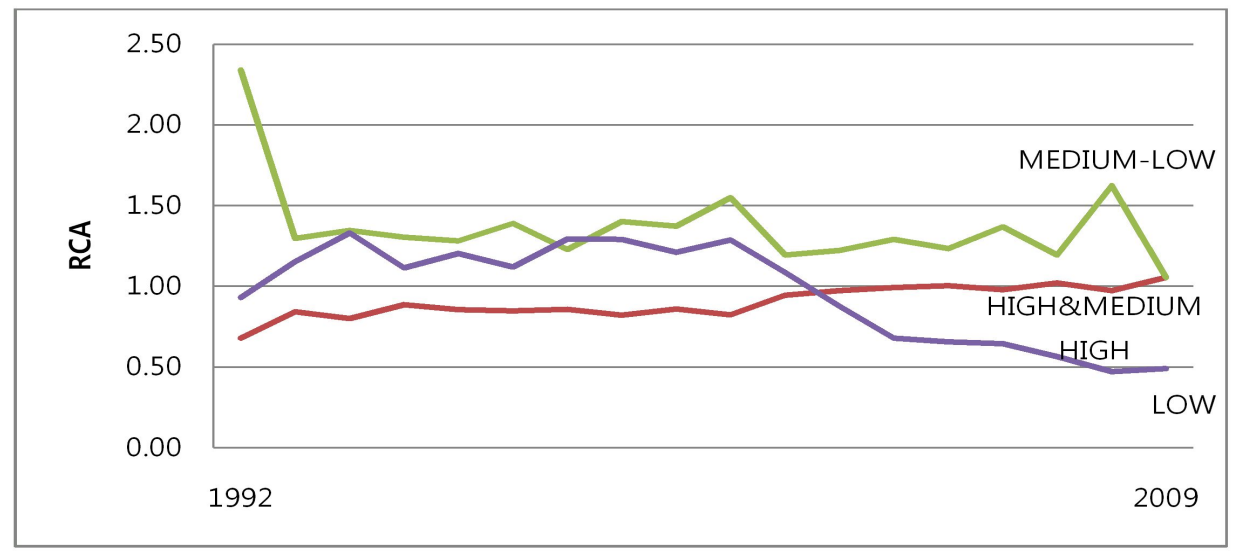

Figure 5.

Korea's RCA trend by technology level in China 


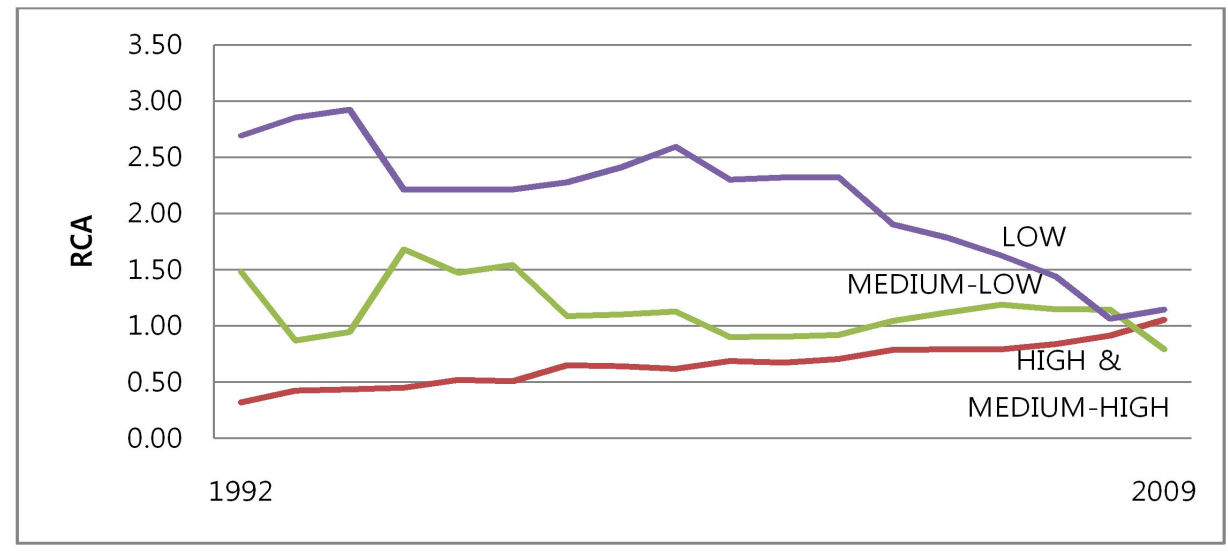

Figure 6.

China's RCA trend by technology level in Korea

The reason why Korea and China exhibited a difference in the RCA in the world market and in the other country's market is related to the economic structure, and the characteristics of trade. Although Korea and China have complementary structured economies, these complementarities are not as strong as when compared to their relationships with other major trading countries. For example, when comparing China-US trade to China-Korea trade. The China-US pair has a stronger complementary economic structure than that of the China-Korea pair. A related and more important reason is that trade between Korea and China is part of a tripartite trade flow which involves advanced countries as the final destination. Korea exports parts and intermediate goods to China, and China makes the finished goods for final exports to the US or Europe. Some Korean companies import raw materials and parts from their subsidiaries in China, and the final process is performed at the home company in Korea and the products are then exported to a third market. In this tripartite type of trade, the revealed comparative advantage is calculated on a finished product basis and may not reflect the true competitiveness of a country's industry. The RCA of China's products includes the embedded competitiveness of the Korean intermediary goods and the RCA of Korea's products includes that of the subsidiary in China.

\section{E. Revealed Comparative Advantage and Intra-industry Trade}

In order to elaborate on the interrelationship of RCA and Korea-China trade, we examined intra-industry trade, the concept which was developed by Grubel and Lloyd 
(1975). Intra-industry trade is defined as:

$$
I I T_{i j k}=\left\{\left(X_{i j k}+M_{i j k}\right)-\left|X_{i j k}-M_{i j k}\right|\right\} /\left(X_{i j k}+M_{i j k}\right)
$$

Where $X_{i j k}$ is country $i$ 's $j$ industry exports in country $k$, and $M_{i j k}$ is country $i$ 's $j$ industry imports from country $k . I I T_{i j k}$ is the intra-industry index of $j$ industry of bilateral trade between countries $i$ and $k$. By definition $I I T_{i j k}$ is the same as $I I T_{k j i}$. If IIT is 1 , then all trade is intra-industry trade and if 0 , then no intra-industry trade has taken place. The IIT measure is greatly influenced by industry classifications. Suppose that all trade flows are categorized in one big sector and that the IIT will be equal to 1. In order to avoid this grouping problem, we used the method suggested by Yarbrough and Yarbrough (2006)

$$
I I T_{i j k}=\left\{\Sigma_{j}\left(X_{i j k}+M_{i j k}\right)-\Sigma_{j}\left|X_{i j k}-M_{i j k}\right|\right\} / \Sigma_{j}\left(X_{i j k}+M_{i j k}\right)
$$

We measured the intra-industry trade index between Korea and China by checking the technology level, and the results are presented in table 8 and figure 7 . We note that the intra-industry trade index between Korea and China is relatively high for a SITC three digit level analysis. According to Hecketh (1973), the intra-industry index which measured at a two digit level in Asia was 0.2 and in Korea 0.05 in 1962. Since the IIT index was measured from a two digit level (a bigger group than a three digit level classification) it should normally produce a higher level, Hecketh's finding suggests that the intra-industry in Asia was at a very low level in 1962. However, our measure of intra-industry trade for Korea and China between 1992-2009 exhibits a high level on the IIT index even when calculated at the three digit level. In the high and medium-high technology industries, the IIT was 0.29 in 1992, and increased to 0.51 in 2009. A similar level and trend was found in the medium-low technology industry: 0.28 in 1992 and 0.53 in 2009. In the low technology level industry, intra-industry trade has increased over time, but the IIT level was lower than the other two groups: 0.19 in 1992 and 0.35 in 2009. The active intra-industry trade between Korea and China particularly in high and medium-high technology industries suggests two plausible implications with regard to RCA. The first is that the 'revealed' comparative advantage of China's high and medium-high tech products includes that of Korean products traded in the form of intra-industrial trade. So China's RCA may be overestimated. The second implication is that China's competitiveness in the high technology category was enhanced as intra-industry trade expanded and consequently knowledge and experience accumulated. It is difficult to clarify which interpretation is 
more feasible, but at least we can assume that intra-industry trade is related to the 'revealed' comparative advantage.

Table 8.

Table intra-industry trade index between Korea and China by technology level

\begin{tabular}{|c|c|c|c|}
\hline & 1992 & 2000 & 2009 \\
\hline HIGH \& MEDIUM-HIGH & 0.29 & 0.51 & 0.51 \\
\hline MEDIUM LOW & 0.28 & 0.36 & 0.53 \\
\hline LOW & 0.19 & 0.32 & 0.35 \\
\hline
\end{tabular}

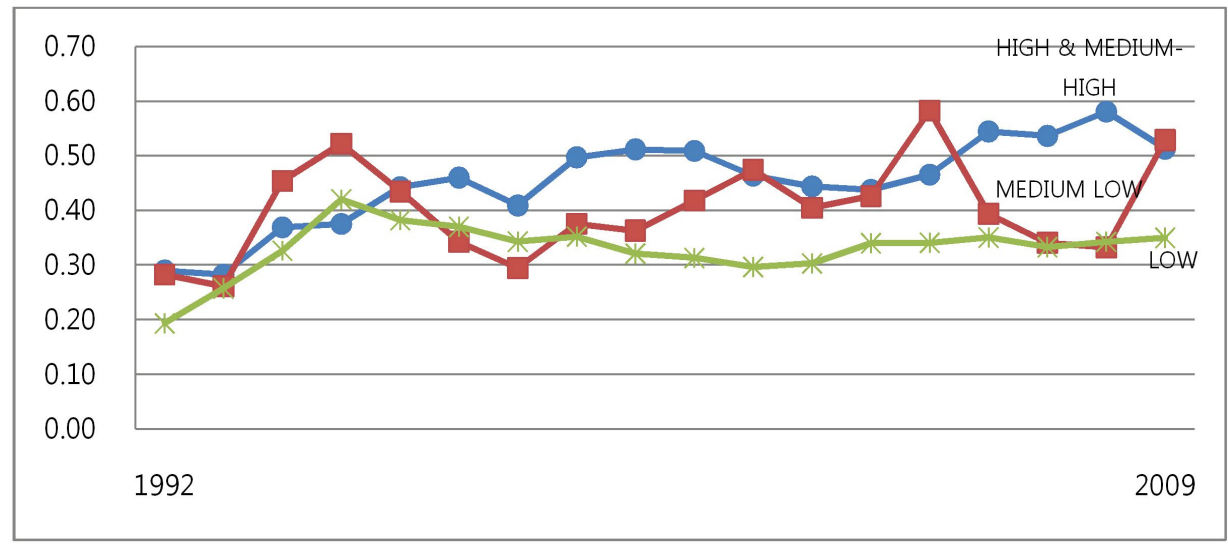

Figure 7.

Intra-industry trade's trend between Korea and China by technology level

\section{F. Comparison of Unit Value of Korea's and China's Export Products}

Since the difference in technology levels is often reflected in the market value of products, we compare the unit value of Korea's exports and China's exports. The unit value can be drawn from UNCOMTRADE data which provides the amount and volume of trade. The amount is expressed in US dollars and the volume is expressed in metric tons. By dividing the export amount by the export volume, we can estimate the unit value of the products of the exporting country. However, measuring trade volume by one single unit (metric tons) seems to be an oversimplification for the variety of different products which ranges from parts, to intermediate goods and finished goods. Therefore, our comparison of 
unit value is made with regards to the basic materials which cover chemicals, steel and non-ferrous metals and are usually traded in units of weight. Figure 8 and table 9 provide the results of the comparison for the unit value of Korea's and China's export products. It can be seen from figure 8 that Korea's export product unit value is higher than that of China's throughout this period. In other words, Korea's chemicals, steel and non-ferrous and other basic materials are, in general, more expensive than China's. Although there may be other factors affecting the price, we believe that a key factor affecting the price is the quality of the products and the quality difference in the basic materials which comes from the technology gap. So, the result suggests that Korea's technology in basic materials is above the level of China's. However, it is also important to note that the gap is reducing. In 1992, China's unit value was only about $30 \%$ of Korea's, but it increased to $70 \%$ in 1995 , $90 \%$ in 2000 , and $95 \%$ in 2009 (table 9).

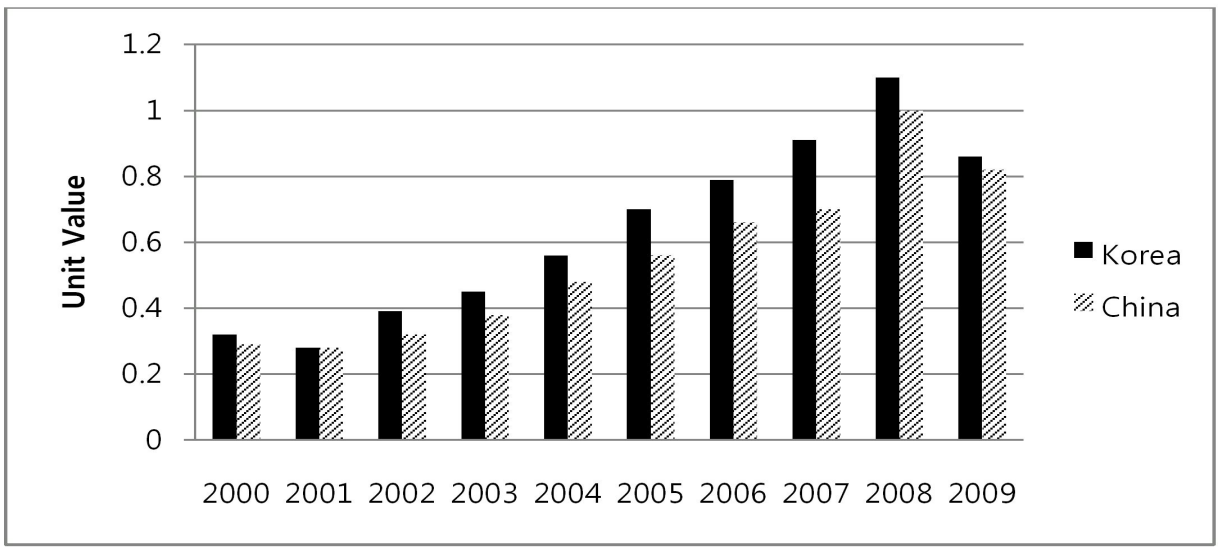

Figure 8.

Unit value of basic materials of Korea's and China's exports

Note: Unit value is calculated from the export amount/export volume in UNCOMTRADE data. The number represents the average export amount which is expressed in US dollars per kilogram of basic material.

Table 9.

Comparison of the unit value of basic material of Korea's and China's exports

\begin{tabular}{|c|c|c|c|c|c|}
\hline & 1992 & 1995 & 2000 & 2005 & 2009 \\
\hline Korea & 0.36 & 0.37 & 0.32 & 0.7 & 0.86 \\
\hline China & 0.11 & 0.26 & 0.29 & 0.56 & 0.82 \\
\hline China/Korea (\%) & 30.56 & 70.27 & 90.63 & 80.00 & 95.35 \\
\hline
\end{tabular}




\section{G. Difference in Technology Levels in the Semi-conductor Industry}

As explained in the preceding subsection, the unit value derived from the trade data has limited usage particularly with regards to sophisticated products which require high technology levels. In this regard, the Ministry of Knowledge and Economy (2010) which describes the differences in technology levels in the semi-conductor chip industry (one of the most advanced high-tech industries) provides us with useful information. In table 10, the top technology level which a country can receive in the category is 100 , and the numbers of other countries show their technology levels relative to the top. For example, in system semi-conductors, the U. S. (100) is at the top, and Japan is a bit behind with 95.9. Korea's technology in that category is (83.7) which falls somewhat behind that of the U.S. and Japan, but is far ahead to China's 69.7. In the semi-conductor process, Korea's technology (99.7) is above the U.S. (99.6), and very close to the top, Japan (100). China's technology in the semi-conductor process is only 76.5, implying that there is a substantial gap in the technology level between Korea and China. The smallest gap between Korea and China is found in package/PCB, where Korea is 95.0 and China 90.0. In summary, Korea has a higher technology level in semi-conductor industry than China, but in some sub-categories China is quickly catching up. In terms of timing, it should take about 3 years for China to approach Korea's level in the semi-conductor process, but only about 1.5 years in the package/PCB.

Table 10.

Comparison of semi-conductor chip technology by country

\begin{tabular}{|c|c|c|c|c|}
\hline & USA & JAPAN & KOREA & CHINA \\
\hline System semi-conductor & 100 & 95.9 & 83.7 & 69.7 \\
\hline Specialized device & 100 & 95.2 & 84.7 & 73.9 \\
\hline Semi-conductor memory chips & 98.5 & 100 & 96.9 & 76.6 \\
\hline Semi-conductor manufacturing process & 99.6 & 100 & 99.7 & 76.5 \\
\hline Semi-conductor equipment & 100 & 99.4 & 81.1 & 59.5 \\
\hline Semi-conductor device & 98.6 & 100 & 83.9 & 68.5 \\
\hline Package PCB & 92.0 & 100 & 95.0 & 90.0 \\
\hline
\end{tabular}

Note: The top country is 100, and numbers of the other countries show their technology levels relative to the top. Source: Ministry of Knowledge Economy (2010), Medium and Long Term Technology Development Plan 


\section{Conclusion}

We found that revealed comparative advantage has moved from low technology products to high technology products in Korea. Low technology level product such as textiles which had a comparative advantage in 1992 lost their competitiveness by 2009, but high-tech products including information technology (IT) products gained a comparative advantage between 1992-2009. In China, the comparative advantage of low technology products was reduced over time, but still remained in 2009. Most notably, the comparative advantage of China's high technology has quickly expanded. Classified by four groups, China's RCA in the highest group even exceeded Korea's. But a more reasonable grouping of the three (for example, classifying automobiles and radio receivers within the same top group) leads to the fact that Korea's RCA in the highest technology level is above that of China's. In any case, the perception that China only has a comparative advantage in labor intensive products with low levels of technology should be changed based on our analysis.

The revealed comparative advantage in bilateral trade between Korea and China exhibited a somewhat different pattern from that of world trade. Except that the RCA of Korea's low technology level products exhibited a clear disadvantage of about 0.5 , most RCA indices converged at around 1. This implies that it is very difficult to assess a comparative advantage or disadvantage by these RCAs when measured from the bilateral trade between Korea and China. In this regard, the role of intra-industry trade was examined, and it was found that intra-industry trade between Korea and China was active. Two kinds of interpretations can be made: China's RCA is overestimated, because it includes values of Korean intermediate goods which are traded in the form of intra-industry trade, or China's competitiveness regarding high technology itself has been enhanced, as intra-industry trade has expanded and consequently knowledge and experience have accumulated.

When comparing unit value of basic materials of Korea's and China's exports, we find that Korea's export product price on average is higher than that of China's throughout this period. Assuming that a key factor affecting the price is the quality of the products and that the quality difference comes from the technology gap, the result suggests that Korea's technology is above the level of China. Another notable finding is that the gap in unit value for basic materials between Korea and China is reducing. Similar technology gaps between Korea and China exist in the semi-conductor industry, one of the most advanced high-tech industries. According to the Ministry of Knowledge and Economy (2010), Korea has a higher technology level in the semi-conductor industry than China, but in some sub-categories like semi-conductor packaging, China is quickly catching up. 
With regards to Korea's concern regarding increased competition from China, our overall assessment is that Korea (and other countries as well) certainly need to pay attention to China, but should not overestimate its comparative advantage in technology intensive products as a threat. Although China gained a comparative advantage in high-tech products, it is still lower than that of Korea. The revealed comparative advantage of China is based on the export of finished goods, and hence does not necessarily reflect the added value of China. The question is how soon this gap will be reduced. In basic materials, we found that the gap became quite close in 2009, but in the semi-conductor industry Korea is much closer to the U.S. and Japan than China is to Korea. 


\section{Reference}

Balassa B.(1965), Trade Liberalisation and Revealed Comparative Advantage, Manchester School of Economic and Social Studies, vol. 33, no. 2, pp.99-123

Brasili Andrea, Paolo Epifani, Rodolfo Helg(2000), On the Dynamics of Trade Patterns. DeEconomist, vol.148, no.2

Dalum Bent, Keld Laursen, Gert Villumsen(1998), Structural Change in OECD Export Specialisation Patterns: De-Specialisation and stickiness. International Review of Applied Economics, vol.12, no.3

Grubel H. G. \& P. J. Lloyd(1975), Intra-Industry Trade. London:TheMaCmillanPress,ltd.

Hecketh, B(1973), Intra-Industry Trade Specialisation in South-East Asia, unpublished M.A. thesis (Canberra: Australian National University)

Hyun, Jung-Taik, Moon joong Tcha(2007), The Rise of China: To Whom is it Scary? Journal of International Logistics and Trade, vol.5,no.2,pp.23-44

Ministry of Knowledge Economy (2010), Medium and Long Term Technology Development Plan

Yarbrough Beth V. \& Yarbrough Robert M.(2006), The World Economy: Trade and Finance, Mason,OH:Thomson/South-Western

OECD STAN DB, http://stats.oecd.org/index.aspx

UN COMTRADE, http://comtrade.un.org/db

UN Statistics Division, http://unstats.un.org/unsd/default.htm 
Annex 1.

SITC Rev3 3-digit

\begin{tabular}{|c|c|}
\hline digit & Description \\
\hline 111 & NONALCOHOLIC BEVERAGES, N.E.S. \\
\hline 112 & ALCOHOLIC BEVERAGES \\
\hline 121 & TOBACCO, UNMANUFACTURED; TOBACCO REFUSE \\
\hline 122 & $\begin{array}{l}\text { TOBACCO, MANUFACTURED (WHETHER OR NOT CONTAINING TOBACCO } \\
\text { SUBSTITUTES) }\end{array}$ \\
\hline 211 & HIDES AND SKINS (EXCEPT FURSKINS), RAW \\
\hline 212 & $\begin{array}{l}\text { FURSKINS, RAW (INCLUDING FURSKIN HEADS, TAILS AND OTHER } \\
\text { PIECES OR CUTTINGS, SUITABLE FOR FURRIERS' USE) }\end{array}$ \\
\hline 222 & $\begin{array}{l}\text { OIL SEEDS AND OLEAGINOUS FRUITS USED FOR THE EXTRACTION OF } \\
\text { SOFT FIXED VEGETABLE OILS (EXCLUDING FLOURS AND MEALS) }\end{array}$ \\
\hline 223 & $\begin{array}{l}\text { OIL SEEDS AND OLEAGINOUS FRUITS, WHOLE OR BROKEN, OF A KIND } \\
\text { USED FOR EXTRACTING OTHER FIXED VEGETALBE OILS (INCLUDING } \\
\text { THEIR FLOURS AND MEALS, N.E.S.) }\end{array}$ \\
\hline 231 & $\begin{array}{l}\text { NATURAL RUBBER, BALATA, GUTTA-PERCHA, GUAYULE, CHICLE AND } \\
\text { SIMILAR NATURAL GUMS, IN PRIMARY FORMS (INCLUDING LATEX) } \\
\text { OR IN PLATES, SHEETS OR STRIP }\end{array}$ \\
\hline 232 & $\begin{array}{l}\text { SYNTHETIC RUBBER; RECLAIMED RUBBER; WASTE, PAIRINGS AND } \\
\text { SCRAP OF UNHARDENED RUBBER }\end{array}$ \\
\hline 244 & $\begin{array}{l}\text { CORK, NATURAL, RAW AND WASTE (INCLUDING NATURAL CORK IN } \\
\text { BLOCKS OR SHEETS) }\end{array}$ \\
\hline 245 & FUEL WOOD (EXCLUDING WOOD WASTE) AND WOOD CHARCOAL \\
\hline 246 & WOOD IN CHIPS OR PARTICLES AND WOOD WASTE \\
\hline 247 & WOOD IN THE ROUGH OR ROUGHLY SQUARED \\
\hline 248 & WOOD, SIMPLY WORKED AND RAILWAY SLEEPERS OF WOOD \\
\hline 251 & PULP AND WASTE PAPER \\
\hline 261 & SILK TEXTILE FIBERS \\
\hline 263 & COTTON TEXTILE FIBERS \\
\hline 264 & $\begin{array}{l}\text { JUTE AND OTHER TEXTILE BAST FIBERS, N.E.S., RAW OR PROCESSED } \\
\text { BUT NOT SPUN; TOW AND WASTE OF THESE FIBRES (INCLUDING } \\
\text { YARN WASTE AND GARNETTED STOCK) }\end{array}$ \\
\hline 265 & $\begin{array}{l}\text { VEGETABLE TEXTILE FIBERS (OTHER THAN COTTON AND JUTE), RAW } \\
\text { OR PROCESSED BUT NOT SPUN; WASTE OF THESE FIBERS }\end{array}$ \\
\hline 266 & SYNTHETIC FIBERS SUITABLE FOR SPINNING \\
\hline 267 & $\begin{array}{l}\text { MANMADE FIBERS, N.E.S. SUITABLE FOR SPINNING AND WASTE OF } \\
\text { MANMADE FIBERS }\end{array}$ \\
\hline
\end{tabular}




\begin{tabular}{|c|c|}
\hline digit & Description \\
\hline 268 & WOOL AND OTHER ANIMAL HAIR (INCLUDING WOOL TOPS) \\
\hline 269 & WORN CLOTHING AND OTHER WORN TEXTILE ARTICLES; RAGS \\
\hline 272 & FERTILIZER, CRUDE, EXCEPT THOSE OF DIVISION 56, (IMPORTS ONLY) \\
\hline 273 & STONE, SAND AND GRAVEL \\
\hline 274 & SULFUR AND UNROASTED IRON PYRITES \\
\hline 277 & NATURAL ABRASIVES, N.E.S. (INCLUDING INDUSTRIAL DIAMONDS) \\
\hline 278 & CRUDE MINERALS, N.E.S. \\
\hline 281 & IRON ORE AND CONCENTRATES \\
\hline 282 & FERROUS WASTE AND SCRAP; REMELTING INGOTS OF IRON OR STEEL \\
\hline 283 & $\begin{array}{l}\text { COPPER ORES AND CONCENTRATES; COPPER MATTES; CEMENT } \\
\text { COPPER }\end{array}$ \\
\hline 284 & $\begin{array}{l}\text { NICKEL ORES AND CONCENTRATES; NICKEL MATTES, NICKEL OXIDE } \\
\text { SINTERS AND OTHER INTERMEDIATE PRODUCTS OF NICKEL } \\
\text { METALLURGY }\end{array}$ \\
\hline 285 & ALUMINUM ORES AND CONCENTRATES (INCLUDING ALUMINA) \\
\hline 287 & ORES AND CONCENTRATES OF BASE METALS, N.E.S. \\
\hline 288 & NONFERROUS BASE METAL WASTE AND SCRAP, N.E.S. \\
\hline 289 & $\begin{array}{l}\text { ORES AND CONCENTRATES OF PRECIOUS METALS; WASTE, SCRAP } \\
\text { AND SWEEPINGS OF PRECIOUS METALS (OTHER THAN GOLD) }\end{array}$ \\
\hline 291 & CRUDE ANIMAL MATERIALS, N.E.S. \\
\hline 292 & CRUDE VEGETABLE MATERIALS, N.E.S. \\
\hline 321 & COAL, PULVERIZED OR NOT, BUT NOT AGGLOMERATED \\
\hline 322 & BRIQUETTES, LIGNITE AND PEAT \\
\hline 325 & $\begin{array}{l}\text { COKE AND SEMICOKE (INCLUDING CHAR) OF COAL, OF LIGNITE OR OF } \\
\text { PEAT, AGGLOMERATED OR NOT; RETORT CARBON }\end{array}$ \\
\hline 333 & PETROLEUM OILS AND OILS FROM BITUMINOUS MINERALS, CRUDE \\
\hline 334 & $\begin{array}{l}\text { PETROLEUM OILS AND OILS FROM BITUMINOUS MINERALS (OTHER } \\
\text { THAN CRUDE), AND PRODUCTS THEREFROM CONTAINING 70\% (BY } \\
\text { WT) OR MORE OF THESE OILS, N.E.S. }\end{array}$ \\
\hline 335 & RESIDUAL PETROLEUM PRODUCTS, N.E.S. AND RELATED MATERIALS \\
\hline 342 & LIQUEFIED PROPANE AND BUTANE \\
\hline 343 & NATURAL GAS, WHETHER OR NOT LIQUEFIED \\
\hline 344 & PETROLEUM GASES AND OTHER GASEOUS HYDROCARBONS, N.E.S. \\
\hline
\end{tabular}




\begin{tabular}{|c|l|}
\hline digit & \multicolumn{1}{|c|}{ Description } \\
\hline 411 & ANIMAL OILS AND FATS \\
\hline 421 & $\begin{array}{l}\text { FIXED VEGETABLE FATS AND OILS, SOFT, CRUDE, REFINED OR } \\
\text { FRACTIONATED }\end{array}$ \\
\hline 422 & $\begin{array}{l}\text { FIXED VEGETABLE FATS AND OILS (OTHER THAN SOFT), CRUDE, } \\
\text { REFINED OR FRACTIONATED }\end{array}$ \\
\hline 431 & $\begin{array}{l}\text { ANIMAL OR VEGETABLE FATS AND OILS PROCESSED; WAXES AND } \\
\text { INEDIBLE MIXTURES OR PREPARATIONS OF ANIMAL OR VEGETABLE } \\
\text { FATS OR OILS, N.E.S. }\end{array}$ \\
\hline 511 & $\begin{array}{l}\text { HYDROCARBONS, N.E.S. AND THEIR HALOGENATED, SULFONATED, } \\
\text { NITRATED OR NITROSATED DERIVATIVES }\end{array}$ \\
\hline 512 & $\begin{array}{l}\text { ALCOHOLS, PHENOLS, PHENOL-ALCOHOLS AND THEIR HALOGENATED, } \\
\text { SULFONATED, NITRATED OR NITROSATED DERIVATIVES }\end{array}$ \\
\hline 513 & $\begin{array}{l}\text { CARBOXYLIC ACIDS AND ANHYDRIDES, HALIDES, PEROXIDES AND } \\
\text { PEROXYACIDS; THEIR HALOGENATED, SULFONATED, NITRATED OR }\end{array}$ \\
\hline 514 & NITROSATED DERIVATIVES \\
\hline 515 & $\begin{array}{l}\text { ORGANO-INORGANIC COMPOUNDS, HETEROCYCLIC COMPOUNDS, } \\
\text { NUCLEIC ACIDS AND THEIR SALTS }\end{array}$ \\
\hline 516 & ORGANIC CHEMICALS, N.E.S. \\
\hline 522 & INORGANIC CHEMICAL ELEMENTS, OXIDES AND HALOGEN SALTS \\
\hline 523 & METALLIC SALTS AND PEROXYSALTS OF INORGANIC ACIDS \\
\hline 524 & $\begin{array}{l}\text { INORGANIC CHEMICALS, N.E.S.; ORGANIC AND INORGANIC } \\
\text { COMPOUNDS OF PRECIOUS METALS }\end{array}$ \\
\hline 525 & RADIOACTIVE AND ASSOCIATED MATERIALS \\
\hline 531 & $\begin{array}{l}\text { SYNTHETIC ORGANIC COLORING MATTER AND COLOR LAKES AND } \\
\text { PREPARATIONS BASED THEREON }\end{array}$ \\
\hline 532 & $\begin{array}{l}\text { DYEING AND TANNING EXTRACTS, AND SYNTHETIC TANNING } \\
\text { MATERIALS }\end{array}$ \\
\hline 533 & PIGMENTS, PAINTS, VARNISHES AND RELATED MATERIALS \\
\hline 541 & $\begin{array}{l}\text { MEDICINAL AND PHARMACEUTICAL PRODUCTS, OTHER THAN } \\
\text { MEDICAMENTS (OF GROUP 542) }\end{array}$ \\
\hline 542 & MEDICAMENTS (INCLUDING VETERINARY MEDICAMENTS) \\
\hline 551 & ESSENTIAL OILS, PERFUME AND FLAVOR MATERIALS \\
\hline 553 & $\begin{array}{l}\text { PERFUMERY, COSMETICS, OR TOILET PREPARATIONS, EXCLUDING } \\
\text { SOAPS }\end{array}$ \\
\hline
\end{tabular}




\begin{tabular}{|c|c|}
\hline digit & Description \\
\hline 554 & SOAP, CLEANSING AND POLISHING PREPARATIONS \\
\hline 562 & $\begin{array}{l}\text { FERTILIZERS (EXPORTS INCLUDE GROUP 272; IMPORTS EXCLUDE } \\
\text { GROUP 272) }\end{array}$ \\
\hline 571 & POLYMERS OF ETHYLENE, IN PRIMARY FORMS \\
\hline 572 & POLYMERS OF STYRENE, IN PRIMARY FORMS \\
\hline 573 & $\begin{array}{l}\text { POLYMERS OF VINYL CHLORIDE OR OTHER HALOGENATED OLEFINS, } \\
\text { IN PRIMARY FORMS }\end{array}$ \\
\hline 574 & $\begin{array}{l}\text { POLYACETALS, OTHER POLYETHERS AND EPOXIDE RESINS, IN } \\
\text { PRIMARY FORMS; POLYCARBONATES, ALKYD RESINS AND OTHER } \\
\text { POLYESTERS, IN PRIMARY FORMS }\end{array}$ \\
\hline 575 & PLASTICS, N.E.S., IN PRIMARY FORMS \\
\hline 579 & WASTE, PARINGS AND SCRAP, OF PLASTICS \\
\hline 581 & TUBES, PIPES AND HOSES OF PLASTICS \\
\hline 582 & PLATES, SHEETS, FILM, FOIL AND STRIP OF PLASTICS \\
\hline 583 & $\begin{array}{l}\text { MONOFILAMENT WITH A CROSS-SECTIONAL DIMENSION EXCEEDING } \\
1 \text { MM, RODS, STICKS AND PROFILE SHAPES OF PLASTICS, NOT MORE } \\
\text { THAN SURFACE-WORKED }\end{array}$ \\
\hline 591 & $\begin{array}{l}\text { INSECTICIDES, FUNGICIDES, HERBICIDES, PLANT GROWTH REGULATORS, } \\
\text { ETC., DISINFECTANTS AND SIMILAR PRODUCTS, PUT UP OR PACKED } \\
\text { FOR RETAIL SALE, ETC. }\end{array}$ \\
\hline 592 & $\begin{array}{l}\text { STARCHES, INULIN AND WHEAT GLUTEN; ALBUMINOIDAL SUBSTANCES; } \\
\text { GLUES }\end{array}$ \\
\hline 593 & EXPLOSIVES AND PYROTECHNIC PRODUCTS \\
\hline 597 & $\begin{array}{l}\text { PREPARED ADDITIVES FOR MINERAL OILS ETC.; LIQUIDS FOR } \\
\text { HYDRAULIC TRANSMISSIONS; ANTIFREEZES AND DEICING FLUIDS; } \\
\text { LUBRICATING PREPARATIONS }\end{array}$ \\
\hline 598 & MISCELLANEOUS CHEMICAL PRODUCTS, N.E.S. \\
\hline 611 & LEATHER \\
\hline 612 & $\begin{array}{l}\text { MANUFACTURES OF LEATHER OR COMPOSITION LEATHER, N.E.S.; } \\
\text { SADDLERY AND HARNESS }\end{array}$ \\
\hline 613 & $\begin{array}{l}\text { FURSKINS, TANNED OR DRESSED (INCLUDING PIECES OR CUTTINGS), } \\
\text { ASSEMBLED OR UNASSEMBLED WITHOUT THE ADDITION OF OTHER } \\
\text { MATERIALS, OTHER THAN APPAREL, ETC. }\end{array}$ \\
\hline 621 & $\begin{array}{l}\text { MATERIALS OF RUBBER, INCLUDING PASTES, PLATES, SHEETS, RODS, } \\
\text { THREAD, TUBES, ETC. }\end{array}$ \\
\hline 625 & $\begin{array}{l}\text { RUBBER TIRES, INTERCHANGEABLE TIRE TREADS, TIRE FLAPS AND } \\
\text { INNER TUBES FOR WHEELS OF ALL KINDS }\end{array}$ \\
\hline
\end{tabular}




\begin{tabular}{|c|c|}
\hline digit & Description \\
\hline 629 & ARTICLES OF RUBBER, N.E.S. \\
\hline 633 & CORK MANUFACTURES \\
\hline 634 & $\begin{array}{l}\text { VENEERS, PLYWOOD, PARTICLE BOARD, AND OTHER WOOD, } \\
\text { WORKED, N.E.S. }\end{array}$ \\
\hline 635 & WOOD MANUFACTURES, N.E.S. \\
\hline 641 & PAPER AND PAPERBOARD \\
\hline 642 & $\begin{array}{l}\text { PAPER AND PAPERBOARD, CUT TO SIZE OR SHAPE, AND ARTICLES OF } \\
\text { PAPER OR PAPERBOARD }\end{array}$ \\
\hline 651 & TEXTILE YARN \\
\hline 652 & $\begin{array}{l}\text { COTTON FABRICS, WOVEN (NOT INCLUDING NARROW OR SPECIAL } \\
\text { FABRICS) }\end{array}$ \\
\hline 653 & $\begin{array}{lcccc}\text { WOVEN } & \text { FABRICS OF } \\
\text { INCLUDING NARROW OR SPECIAL FABRICS) } & & \end{array}$ \\
\hline 654 & $\begin{array}{l}\text { WOVEN FABRICS OF TEXTILE MATERIALS, OTHER THAN COTTON OR } \\
\text { MANMADE FIBERS AND NARROW OR SPECIAL FABRICS }\end{array}$ \\
\hline 655 & $\begin{array}{l}\text { KNITTED OR CROCHETED FABRICS (INCLUDING TUBULAR KNIT } \\
\text { FABRICS, N.E.S., PILE FABRICS AND OPEN-WORK FABRICS), N.E.S. }\end{array}$ \\
\hline 656 & $\begin{array}{l}\text { TULLES, LACE, EMBROIDERY, RIBBONS, TRIMMINGS AND OTHER } \\
\text { SMALL WARES }\end{array}$ \\
\hline 657 & SPECIAL YARNS, SPECIAL TEXTILE FABRICS AND RELATED PRODUCTS \\
\hline 658 & $\begin{array}{l}\text { MADE-UP ARTICLES, WHOLLY OR CHIEFLY OF TEXTILE MATERIALS, } \\
\text { N.E.S. }\end{array}$ \\
\hline 659 & FLOOR COVERINGS, ETC. \\
\hline 661 & $\begin{array}{l}\text { LIME, CEMENT, AND FABRICATED CONSTRUCTION MATERIALS, } \\
\text { EXCEPT GLASS AND CLAY MATERIALS }\end{array}$ \\
\hline 662 & $\begin{array}{lclll}\text { CLAY CONSTRUCTION } & \text { MATERIALS } & \text { AND } & \text { REFRACTORY } \\
\text { CONSTRUCTION MATERIALS } & & & \\
\end{array}$ \\
\hline 663 & MINERAL MANUFACTURES, N.E.S. \\
\hline 664 & GLASS \\
\hline 665 & GLASSWARE \\
\hline 666 & POTTERY \\
\hline 667 & $\begin{array}{l}\text { PEARLS, PRECIOUS AND SEMIPRECIOUS STONES, UNWORKED OR } \\
\text { WORKED }\end{array}$ \\
\hline 671 & $\begin{array}{l}\text { PIG IRON AND SPIEGELEISEN, SPONGE IRON, IRON OR STEEL } \\
\text { GRANULES AND POWDERS AND FERROALLOYS }\end{array}$ \\
\hline 672 & $\begin{array}{l}\text { IRON OR STEEL INGOTS AND OTHER PRIMARY FORMS, AND } \\
\text { SEMIFINISHED PRODUCTS OF IRON OR STEEL }\end{array}$ \\
\hline
\end{tabular}




\begin{tabular}{|c|c|}
\hline digit & Description \\
\hline 673 & $\begin{array}{l}\text { IRON OR NONALLOY STEEL FLAT-ROLLED PRODUCTS, NOT CLAD, } \\
\text { PLATED OR COATED }\end{array}$ \\
\hline 674 & $\begin{array}{l}\text { IRON AND NONALLOY STEEL FLAT-ROLLED PRODUCTS, CLAD, } \\
\text { PLATED OR COATED }\end{array}$ \\
\hline 675 & ALLOY STEEL FLAT-ROLLED PRODUCTS \\
\hline 676 & $\begin{array}{l}\text { IRON AND STEEL BARS, RODS, ANGLES, SHAPES AND SECTIONS, } \\
\text { INCLUDING SHEET PILING }\end{array}$ \\
\hline 677 & $\begin{array}{l}\text { IRON AND STEEL RAILS AND RAILWAY TRACK CONSTRUCTION } \\
\text { MATERIAL }\end{array}$ \\
\hline 678 & IRON AND STEEL WIRE \\
\hline 679 & $\begin{array}{l}\text { IRON AND STEEL TUBES, PIPES AND HOLLOW PROFILES, FITTINGS FOR } \\
\text { TUBES AND PIPES }\end{array}$ \\
\hline 681 & SILVER, PLATINUM AND OTHER PLATINUM GROUP METALS \\
\hline 682 & COPPER \\
\hline 683 & NICKEL \\
\hline 684 & ALUMINUM \\
\hline 685 & LEAD \\
\hline 686 & ZINC \\
\hline 687 & TIN \\
\hline 689 & $\begin{array}{llllll}\text { MISCELLANEOUS NONFERROUS } & \text { BASE } & \text { METALS } & \text { EMPLOYED } & \text { IN } \\
\text { METALLURGY AND CERMETS } & & & & \\
\end{array}$ \\
\hline 691 & $\begin{array}{l}\text { METAL STRUCTURES AND PARTS, N.E.S., OF IRON, STEEL OR } \\
\text { ALUMINUM }\end{array}$ \\
\hline 692 & METAL CONTAINERS FOR STORAGE OR TRANSPORT \\
\hline 693 & $\begin{array}{l}\text { WIRE PRODUCTS (EXCLUDING INSULATED ELECTRICAL WIRING) AND } \\
\text { FENCING GRILLS }\end{array}$ \\
\hline 694 & $\begin{array}{l}\text { NAILS, SCREWS, NUTS, BOLTS, RIVETS AND SIMILAR ARTICLES, OF } \\
\text { IRON, STEEL, COPPER OR ALUMINUM }\end{array}$ \\
\hline 695 & TOOLS FOR USE IN THE HAND OR IN MACHINES \\
\hline 696 & CUTLERY \\
\hline 697 & HOUSEHOLD EQUIPMENT OF BASE METAL, N.E.S. \\
\hline 699 & MANUFACTURES OF BASE METAL, N.E.S. \\
\hline 711 & $\begin{array}{l}\text { STEAM OR OTHER VAPOR GENERATING BOILERS, SUPER-HEATED } \\
\text { WATER BOILERS AND AUXILIARY PLANT FOR USE THEREWITH; AND } \\
\text { PARTS THEREOF }\end{array}$ \\
\hline
\end{tabular}




\begin{tabular}{|c|c|}
\hline digit & Description \\
\hline 712 & $\begin{array}{l}\text { STEAM TURBINES AND OTHER VAPOR TURBINES, AND PARTS } \\
\text { THEREOF, N.E.S. }\end{array}$ \\
\hline 713 & $\begin{array}{l}\text { INTERNAL COMBUSTION PISTON ENGINES AND PARTS THEREOF, } \\
\text { N.E.S. }\end{array}$ \\
\hline 714 & $\begin{array}{l}\text { ENGINES AND MOTORS, NONELECTRIC (OTHER THAN STEAM } \\
\text { TURBINES, INTERNAL COMBUSTION PISTON ENGINES AND POWER } \\
\text { GENERATING MACHINERY); PARTS THEREOF, N.E.S. }\end{array}$ \\
\hline 716 & ROTATING ELECTRIC PLANT AND PARTS THEREOF, N.E.S. \\
\hline 718 & POWER GENERATING MACHINERY AND PARTS THEREOF, N.E.S. \\
\hline 721 & $\begin{array}{l}\text { AGRICULTURAL MACHINERY (EXCLUDING TRACTORS) AND PARTS } \\
\text { THEREOF }\end{array}$ \\
\hline 722 & TRACTORS (OTHER THAN MECHANICAL HANDLING EQUIPMENT) \\
\hline 723 & CIVIL ENGINEERING AND CONTRACTORS' PLANT AND EQUIPMENT \\
\hline 724 & TEXTILE AND LEATHER MACHINERY, AND PARTS THEREOF, N.E.S. \\
\hline 725 & $\begin{array}{l}\text { PAPER MILL AND PULP MILL MACHINERY, PAPER CUTTING MACHINES } \\
\text { AND MACHINERY FOR THE MANUFACTURE OF PAPER ARTICLES; } \\
\text { PARTS THEREOF }\end{array}$ \\
\hline 726 & PRINTING AND BOOKBINDING MACHINERY, AND PARTS THEREOF \\
\hline 727 & FOOD-PROCESSING MACHINES (EXCLUDING DOMESTIC) \\
\hline 728 & $\begin{array}{lcccc}\text { MACHINERY AND EQUIPMENT } & \text { SPECIALIZED } & \text { FOR } & \text { PARTICULAR } \\
\text { INDUSTRIES, AND PARTS THHEREOF, N.E.S. } & & \\
\end{array}$ \\
\hline 731 & $\begin{array}{l}\text { MACHINE TOOLS WORKING BY REMOVING METAL OR OTHER } \\
\text { MATERIAL }\end{array}$ \\
\hline 733 & $\begin{array}{l}\text { MACHINE TOOLS FOR WORKING METAL, SINTERED METAL CARBIDES } \\
\text { OR CERMETS, WITHOUT REMOVING MATERIAL }\end{array}$ \\
\hline 735 & $\begin{array}{l}\text { PARTS AND ACCESSORIES SUITABLE FOR USE SOLELY OR } \\
\text { PRINCIPALLY WITH METAL WORKING MACHINE TOOLS, WHETHER OR } \\
\text { NOT REMOVING METAL; HAND HELD TOOL HOLDERS }\end{array}$ \\
\hline 737 & $\begin{array}{l}\text { METALWORKING MACHINERY (OTHER THAN MACHINE TOOLS) AND } \\
\text { PARTS THEREOF, N.E.S. }\end{array}$ \\
\hline 741 & HEATING AND COOLING EQUIPMENT AND PARTS THEREOF, N.E.S. \\
\hline 742 & $\begin{array}{l}\text { PUMPS FOR LIQUIDS, WHETHER OR NOT FITTED WITH A MEASURING } \\
\text { DEVICE; LIQUID ELEVATORS; PARTS FOR SUCH PUMPS AND LIQUID } \\
\text { ELEVATORS }\end{array}$ \\
\hline 743 & $\begin{array}{l}\text { PUMPS (NOT FOR LIQUIDS), AIR OR GAS COMPRESSORS AND FANS; } \\
\text { VENTILATING HOODS INCORPORATING A FAN; CENTRIFUGES; } \\
\text { FILTERING ETC. APPARATUS; PARTS THEREOF }\end{array}$ \\
\hline 744 & 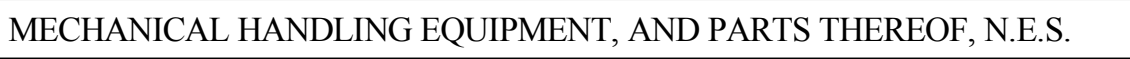 \\
\hline
\end{tabular}




\begin{tabular}{|c|c|}
\hline digit & Description \\
\hline 745 & 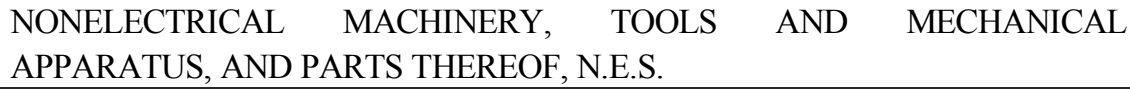 \\
\hline 746 & BALL OR ROLLER BEARINGS \\
\hline 747 & $\begin{array}{l}\text { TAPS, COCKS, VALVES AND SIMILAR APPLIANCES FOR PIPES, BOILER } \\
\text { SHELLS, TANKS, ETC. (INCLUDING PRESSURE AND TEMPERATURE } \\
\text { CONTROLLED VALVES) }\end{array}$ \\
\hline 748 & $\begin{array}{l}\text { TRANSMISSION SHAFTS AND CRANKS; BEARING HOUSINGS AND } \\
\text { PLAIN SHAFT BEARINGS; GEARS AND GEARING; BALL SCREWS; GEAR } \\
\text { BOXES, CLUTCHES, ETC.; PARTS THEREOF }\end{array}$ \\
\hline 749 & NONELECTRIC PARTS AND ACCESSORIES OF MACHINERY, N.E.S. \\
\hline 751 & OFFICE MACHINES \\
\hline 752 & $\begin{array}{l}\text { AUTOMATIC DATA PROCESSING MACHINES AND UNITS THEREOF; } \\
\text { MAGNETIC OR OPTICAL READERS; MACHINES TRANSCRIBING CODED } \\
\text { MEDIA AND PROCESSING SUCH DATA, N.E.S. }\end{array}$ \\
\hline 761 & $\begin{array}{l}\text { TV RECEIVERS (INCLUDING VIDEO MONITORS \& PROJECTORS) WHETH } \\
\text { R NT INCORP RADIOBROADCAST RECEIVERS OR SOUND OR VIDEO } \\
\text { RECORDING OR REPRODUCING APPARATUS }\end{array}$ \\
\hline 762 & $\begin{array}{l}\text { RADIO-BROADCAST RECEIVERS, WHETHER OR NOT INCORPORATING } \\
\text { SOUND RECORDING OR REPRODUCING APPARATUS OR A CLOCK }\end{array}$ \\
\hline 763 & $\begin{array}{l}\text { SOUND RECORDERS OR REPRODUCERS; TELEVISION IMAGE AND } \\
\text { SOUND RECORDERS OR REPRODUCERS }\end{array}$ \\
\hline 764 & $\begin{array}{l}l l \\
\text { TELECOMMUNICATIONS EQUIPMENT, N.E.S.; } \\
\text { ACCESSORIES PARTS, N.E.S., AND } \\
\text { TELECOMMUNICATIONS, ETC. }\end{array}$ \\
\hline 771 & $\begin{array}{l}\text { ELECTRIC POWER MACHINERY (OTHER THAN ROTATING ELECTRIC } \\
\text { PLANT OF POWER GENERATING MACHINERY) AND PARTS THEREOF }\end{array}$ \\
\hline 772 & $\begin{array}{lcccc}\text { ELECTRICAL APPARATUS FOR SWITCHING OR PROTECTING } \\
\text { ELECTRICAL CIRCUITS OR FOR MAKING CONNECTIONS TO OR IN } \\
\text { ELECTRICAL CIRCUITS (EXCLUDING TELEPHONE ETC.) }\end{array}$ \\
\hline 773 & EQUIPMENT FOR DISTRIBUTING ELECTRICITY, N.E.S. \\
\hline 774 & $\begin{array}{lrr}\text { ELECTRO-DIAGNOSTIC APPARATUS } & \text { FOR MEDICAL, SURGICAL, } \\
\text { DENTAL OR VETERINARY SCIENCES AND RADIOLOGICAL APPARATUS }\end{array}$ \\
\hline 775 & $\begin{array}{l}\text { HOUSEHOLD TYPE ELECTRICAL AND NONELECTRICAL EQUIPMENT, } \\
\text { N.E.S. }\end{array}$ \\
\hline 776 & $\begin{array}{l}\text { THERMIONIC, COLD CATHODE OR PHOTOCATHODE VALVES AND } \\
\text { TUBES; DIODES, TRANSISTORS AND SIMILAR SEMICONDUCTOR } \\
\text { DEVICES; INTEGRATED CIRCUITS, ETC.; PARTS }\end{array}$ \\
\hline 778 & ELECTRICAL MACHINERY AND APPARATUS, N.E.S. \\
\hline 781 & MOTOR CARS AND OTHER MOTOR VEHICLES PRINCIPALLY DESIGNED \\
\hline
\end{tabular}




\begin{tabular}{|c|c|}
\hline digit & Description \\
\hline & $\begin{array}{l}\text { FOR THE TRANSPORT OF PERSONS (NOT PUBLIC } \\
\text { TRANSPORT), } \\
\text { INCLUDING STATION WAGONS AND RACING CARS }\end{array}$ \\
\hline 782 & $\begin{array}{l}\text { MOTOR VEHICLES FOR THE TRANSPORT OF GOODS AND SPECIAL } \\
\text { PURPOSE MOTOR VEHICLES }\end{array}$ \\
\hline 783 & ROAD MOTOR VEHICLES, N.E.S. \\
\hline 784 & $\begin{array}{l}\text { PARTS AND ACCESSORIES FOR TRACTORS, MOTOR CARS AND OTHER } \\
\text { MOTOR VEHICLES, TRUCKS, PUBLIC-TRANSPORT VEHICLES AND } \\
\text { ROAD MOTOR VEHICLES N.E.S. }\end{array}$ \\
\hline 785 & $\begin{array}{l}\text { MOTORCYCLES (INCLUDING MOPEDS) AND CYCLES, MOTORIZED AND } \\
\text { NOT MOTORIZED; INVALID CARRIAGES }\end{array}$ \\
\hline 786 & $\begin{array}{l}\text { TRAILERS AND SEMI-TRAILERS; OTHER } \quad \text { VEHICLES, } \\
\text { MECHANICALLY PROPELLED; SPECIALLY DESIGNED AND EQUIPPED } \\
\text { TRANSPORT CONTAINERS }\end{array}$ \\
\hline 791 & $\begin{array}{l}\text { RAILWAY VEHICLES (INCLUDING HOVERTRAINS) AND ASSOCIATED } \\
\text { EQUIPMENT }\end{array}$ \\
\hline 792 & $\begin{array}{l}\text { AIRCRAFT AND ASSOCIATED EQUIPMENT; SPACECRAFT (INCLUDING } \\
\text { SATELLITES) AND SPACECRAFT LAUNCH VEHICLES; AND PARTS } \\
\text { THEREOF }\end{array}$ \\
\hline 793 & 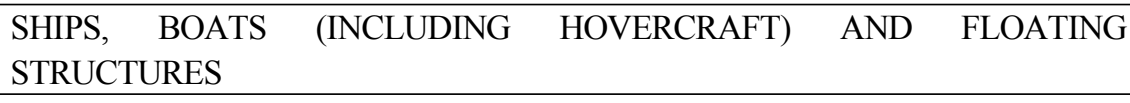 \\
\hline 811 & PREFABRICATED BUILDINGS \\
\hline 812 & SANITARY, PLUMBING AND HEATING FIXTURES AND FITTINGS, N.E.S. \\
\hline 813 & LIGHTING FIXTURES AND FITTINGS, N.E.S. \\
\hline 821 & $\begin{array}{llcl}\text { FURNITURE } & \text { AND PARTS } & \text { THEREOF; } & \text { BEDDING, MATTRESSES, } \\
\text { MATTRESS SUPPORTS, CUSHIONS AND SIMILAR STUFFED } \\
\text { FURNISHINGS }\end{array}$ \\
\hline 831 & $\begin{array}{l}\text { TRUNKS, SUITCASES, VANITY CASES, BINOCULAR AND CAMERA } \\
\text { CASES, HANDBAGS, WALLETS, ETC. OF LEATHER, ETC.; TRAVEL SETS } \\
\text { FOR PERSONAL TOILET, SEWING, ETC. }\end{array}$ \\
\hline 841 & $\begin{array}{l}\text { MEN'S OR BOYS' COATS, JACKETS, SUITS, TROUSERS, SHIRTS, } \\
\text { UNDERWEAR ETC. OF WOVEN TEXTILE FABRICS (EXCEPT SWIMWEAR } \\
\text { AND COATED OR LAMINATED APPAREL) }\end{array}$ \\
\hline 842 & $\begin{array}{l}\text { WOMEN'S OR GIRLS' COATS, CAPES, JACKETS, SUITS, TROUSERS, } \\
\text { DRESSES, SKIRTS, UNDERWEAR, ETC. OF WOVEN TEXTILES (EXCEPT } \\
\text { SWIMWEAR AND COATED ETC. APPAREL) }\end{array}$ \\
\hline 843 & $\begin{array}{l}\text { MEN'S OR BOYS' COATS, CAPES, JACKETS, SUITS, BLAZERS, TROUSERS, } \\
\text { SHIRTS, ETC. (EXCEPT SWIMWEAR OR COATED APPAREL), KNITTED } \\
\text { OR CROCHETED TEXTILE FABRIC }\end{array}$ \\
\hline
\end{tabular}




\begin{tabular}{|c|c|}
\hline digit & Description \\
\hline 844 & $\begin{array}{l}\text { WOMEN'S OR GIRLS' COATS, CAPES, JACKETS, SUITS, TROUSERS, } \\
\text { DRESSES, UNDERWEAR, ETC. (EXCEPT SWIMWEAR AND COATED ETC. } \\
\text { APPAREL), KNITTED OR CROCHETED }\end{array}$ \\
\hline 845 & $\begin{array}{l}\text { ARTICLES OF APPAREL, OF TEXTILE FABRICS, WHETHER OR NOT } \\
\text { KNITTED OR CROCHETED, N.E.S. }\end{array}$ \\
\hline 846 & $\begin{array}{l}\text { CLOTHING ACCESSORIES, OF TEXTILE FABRICS, WHETHER OR NOT } \\
\text { KNITTED OR CROCHETED (OTHER THAN THOSE FOR BABIES) }\end{array}$ \\
\hline 848 & $\begin{array}{l}\text { ARTICLES OF APPAREL AND CLOTHING ACCESSORIES OF OTHER } \\
\text { THAN TEXTILE FABRICS; HEADGEAR OF ALL MATERIALS }\end{array}$ \\
\hline 851 & FOOTWEAR \\
\hline 871 & OPTICAL INSTRUMENTS AND APPARATUS, N.E.S. \\
\hline 872 & $\begin{array}{l}\text { INSTRUMENTS AND APPLIANCES, N.E.S., FOR MEDICAL, SURGICAL, } \\
\text { DENTAL OR VETERINARY PURPOSES }\end{array}$ \\
\hline 873 & METERS AND COUNTERS, N.E.S. \\
\hline 874 & $\begin{array}{l}\text { MEASURING, CHECKING, ANALYSING AND CONTROLLING INSTRUMENTS } \\
\text { AND APPARATUS, N.E.S. }\end{array}$ \\
\hline 881 & PHOTOGRAPHIC APPARATUS AND EQUIPMENT, N.E.S. \\
\hline 882 & PHOTOGRAPHIC AND CINEMATOGRAPHIC SUPPLIES \\
\hline 883 & $\begin{array}{l}\text { CINEMATOGRAPHIC FILM, EXPOSED AND DEVELOPED, WHETHER OR } \\
\text { NOT INCORPORATING SOUND TRACK OR CONSISTING ONLY OF } \\
\text { SOUND TRACK }\end{array}$ \\
\hline 884 & OPTICAL GOODS, N.E.S. \\
\hline 885 & WATCHES AND CLOCKS \\
\hline 891 & ARMS AND AMMUNITION \\
\hline 892 & PRINTED MATTER \\
\hline 893 & ARTICLES, N.E.S. OF PLASTICS \\
\hline 894 & BABY CARRIAGES, TOYS, GAMES AND SPORTING GOODS \\
\hline 895 & OFFICE AND STATIONERY SUPPLIES, N.E.S. \\
\hline 896 & WORKS OF ART, COLLECTORS' PIECES AND ANTIQUES \\
\hline 897 & $\begin{array}{l}\text { JEWELRY, GOLDSMITHS' AND SILVERSMITHS' WARES, AND OTHER } \\
\text { ARTICLES OF PRECIOUS OR SEMIPRECIOUS MATERIALS, N.E.S. }\end{array}$ \\
\hline 898 & $\begin{array}{l}\text { MUSICAL INSTRUMENTS, PARTS AND ACCESSORIES THEREOF; RECORDS, } \\
\text { TAPES AND OTHER SOUND OR SIMILAR RECORDINGS (EXCLUDING } \\
\text { PHOTOGRAPHIC FILM, ETC.) }\end{array}$ \\
\hline 899 & MISCELLANEOUS MANUFACTURED ARTICLES, N.E.S. \\
\hline
\end{tabular}

